\title{
Adsorption Mechanism of Copper and Cadmium onto Defatted Waste Biomass
}

\author{
Fumihiko Ogata, Hisato Tominaga, Hitoshi Yabutani and Naohito Kawasaki* \\ Faculty of Pharmacy, Kinki University (3-4-1 Kowakae, Higashi-Osaka, Osaka 577-8502, JAPAN)
}

\begin{abstract}
In this study, the amount of copper or cadmium adsorbed using waste biomass (i.e., coffee grounds (CG) and rice bran (RB)) was investigated. The amount of crude protein in defatted CG (D-CG) or RB (D-RB) was greater than that in CG or RB, respectively. The amount of copper or cadmium adsorbed using CG was greater than that using RB. Additionally, the amount of copper or cadmium adsorbed was not affected by the presence of fat in CG. Adsorption data was fitted to the Freundlich equation, and the correlation coefficients were in the range of 0.794-0.991. The main adsorption mechanism was thought to be monolayer adsorption onto the surface of the waste biomass. The adsorption rate data was fitted to the pseudo-second-order model, and the correlation coefficient average was in the range of 0.891-0.945. This result showed that the rate-limiting step may be chemisorption. Moreover, the amount of copper or cadmium desorbed from CG or RB using $0.01 \mathrm{~mol} / \mathrm{L}$ or $1.00 \mathrm{~mol} / \mathrm{L} \mathrm{HNO}_{3}$ was investigated. Desorption with $0.01 \mathrm{~mol} / \mathrm{L} \mathrm{HNO}_{3}$ resulted in the recovery of 86-97\% of the copper and cadmium, indicating that copper or cadmium that was adsorbed using waste biomass was recoverable.
\end{abstract}

Key words: defatted, coffee ground, rice bran, adsorption

\section{INTRODUCTION}

Cadmium is an essential element of the human body. It is also found in vegetables, fruits, seafood, meats, and especially rice. In Japan, rice is a predominant food, and therefore, the intake of cadmium in Japan is greater than in foreign countries. Excess intake of cadmium causes chronic poisoning leading to, for example, kidney disease and itaiitai disease in Japan. Therefore, the standard level of cadmium in tap water is strictly regulated in many countries to be less than $0.01 \mathrm{mg} / \mathrm{L}$. Copper is another an essential element of the human body. The standard level of copper in tap water is regulated to be less than $1.0 \mathrm{mg} / \mathrm{L}$. Copper deficiency can cause hemolytic anemia, whereas excess intake causes vomiting, diarrhea, and liver disease. Therefore, it is important to develop removal technologies for these elements.

Coffee grounds (CG) and rice bran (RB) are well-known biomass from waste materials. Approximately 600 thousand tons of CG is generated per year as waste material after the elution of coffee beans, and 900 thousand tons of $\mathrm{RB}$ are generated per year from polished rice. Approximately $10 \%$ of CG and RB are used as agricultural fertilizer, while $90 \%$ of the residues are burned. As the use of these materials as fertilizer increases, the release of carbon dioxide and its contribution to global warming is of concern. More appropriate recycling and reuse of vegetable biomass is important for sustainable development.

The technological uses for vegetable biomass include the adsorption of heavy metals onto, for example, vegetable biomass ${ }^{1-10)}$, mineral natural kaolinite clay or montmorillonite $^{11,12)}$, date pits solid adsorbent ${ }^{13)}$, and algae ${ }^{14-18)}$. We previously reported on the ability of waste biomass to adsorb copper, lead, iron, and cadmium ${ }^{19-22)}$. The abovementioned studies show that biomass is able to adsorb heavy metals. Although fat is a typical component of biomass, no studies have investigated the effect of that fat on heavy metal adsorption. Moreover, only a few studies have investigated the desorption of heavy metals from biomass; therefore, this is an area that requires further investigation. It is crucial to elucidate the underlying mechanisms of heavy metal adsorption onto biomass, as well as those of desorption from the biomass.

In this study, the ability of copper and cadmium to adsorb onto $\mathrm{CG}$ and RB was determined for the development of recycling and reuse technologies. Furthermore, the desorption of copper and cadmium from the biomass using $\mathrm{HNO}_{3}$ was investigated.

\footnotetext{
*Correspondence to: Naohito Kawasaki, Faculty of Pharmacy, Kinki University, 3-4-1 Kowakae, Higashi-Osaka, Osaka 577-8502, JAPAN

E-mail: kawasaki@phar.kindai.ac.jp

Accepted March 5, 2011 (received for review September 24, 2010)
}

Journal of Oleo Science ISSN 1345-8957 print / ISSN 1347-3352 online

http://www.jstage.jst.go.jp/browse/jos/ 


\section{F. Ogata, H. Tominaga, H. Yabutani and N. Kawasaki}

\section{EXPERIMENTAL PROCEDURES}

\subsection{Materials}

$\mathrm{Cd}\left(\mathrm{NO}_{3}\right)_{2}$ and $\mathrm{Cu}\left(\mathrm{NO}_{3}\right)_{2}$ were purchased from Wako Pure Chemical Industries Co., Ltd. Adsorbent CG and RB were obtained from Eybeans and The Osaka Daiichi Rice Deal Co., Ltd., respectively.

\subsection{Characteristics of $C G$ and $R B$}

Defatted CG (D-CG) or defatted RB (D-RB) was prepared as follows: a soxhlet fat extraction apparatus for extraction with ether was used to measure the crude fat content $^{23)}$. A $10.0 \mathrm{~g}$ biomass sample was placed in a cylindrical paper filter and dried at $100-105^{\circ} \mathrm{C}$ for $2-3 \mathrm{~h}$. The flask was half-filled with diethyl ether and extraction was performed for about $8 \mathrm{~h}$. The flask was dried at $98-100^{\circ} \mathrm{C}$ for about 1 $\mathrm{h}$, left to cool in a desiccator, and weighed. The crude fat content was calculated using Eq. (1), as follows:

$$
F=(A-B) \times 100 / 10
$$

where $F$ is the crude fat content (\%), $A$ is the weight (g) of the flask after fat extraction and drying, and $B$ is the weight $(\mathrm{g})$ of the flask before fat extraction.

The crude protein content was calculated using the semi-micro Kjeldahl method ${ }^{24)}$. A 0.02 g portion of the sample, $0.5 \mathrm{~g}$ of a decomposition promoter $\left(\mathrm{K}_{2} \mathrm{SO}_{4}: \mathrm{CuSO}_{4}\right.$. $\left.5 \mathrm{H}_{2} \mathrm{O}=10: 1\right), 3 \mathrm{~mL}$ of concentrated sulfuric acid, and $1 \mathrm{~mL}$ of $30 \mathrm{w} / \mathrm{v} \%$ hydrogen peroxide solution were placed in a decomposition flask and then decomposed by heating. After decomposition, $25 \mathrm{~mL}$ of $30 \mathrm{w} / \mathrm{v} \%$ sodium hydroxide solution were added. Steam distillation was initiated and $100 \mathrm{~mL}$ of distillate was collected as the sample solution. A solution prepared by the addition of $15 \mathrm{~mL}$ of $4 \mathrm{w} / \mathrm{v} \%$ boric acid solution and a few drops of bromocresol green and methyl red were used as the adsorbing solution. The test solution was titrated with a $0.025 \mathrm{~mol} / \mathrm{L}$ sulfuric acid solution, and a blank test was performed using distilled water. The crude protein content was calculated using Eq. (2), as follows:

$$
P=0.7003 \times(a-b) \times 100 \times 6.25 / M
$$

where $P$ is the crude protein content (\%), $a$ is the sulfuric acid titer $(\mathrm{mL})$ required in the main experiment, $b$ is the sulfuric acid titer $(\mathrm{mL})$ required in the blank experiment, $M$ is the sample weight (mg), and 6.25 is the nitrogen coefficient.

The iodine adsorption capacity indicates the specific surface area; the iodine adsorption capacity of the biomass was measured according to JIS K1474 (Japanese Industrial Standard). Biomass was added to a $0.05 \mathrm{~mol} / \mathrm{L}$ iodine solution and the suspension was shaken for 15 min. Any suspended biomass in the iodine solution was separated by filtration. The solution was then titrated with a $0.1 \mathrm{~mol} / \mathrm{L}$ sodium thiosulfate solution. The adsorption capacity for iodine was calculated using Eq. (3), as follows:

$$
I=(10-k) \times 12.69 \times 5 / S
$$

where $I$ is the amount of iodine adsorbed $(\mathrm{mg} / \mathrm{g}), k$ is the volume of sodium thiosulfate solution titrated $(\mathrm{mL})$, and $S$ is the amount of biomass used ( $\mathrm{g}$ ).

The functional groups of the biomass were determined using Boehm's titration method ${ }^{25-27)}$. The dried samples $(1.0 \mathrm{~g})$ were mixed with $100 \mathrm{~mL}$ of a $0.1 \mathrm{~mol} / \mathrm{L} \mathrm{NaOH}$ or $\mathrm{HCl}$ solution. The sample suspensions were shaken for $48 \mathrm{~h}$ at $25^{\circ} \mathrm{C}$. Any excess base or acid in $50 \mathrm{~mL}$ of the filtrates was titrated using $0.1 \mathrm{~mol} / \mathrm{L} \mathrm{HCl}$ or $\mathrm{NaOH}$. The surface acidity or alkalinity was calculated based on the assumption that $\mathrm{NaOH}$ neutralizes all acidic groups, including carboxyl, lactonic, and phenolic groups, and that $\mathrm{HCl}$ neutralizes all basic groups.

\subsection{Adsorption isotherms of copper and cadmium onto biomass}

Biomass (0.05 g) was added to $50 \mathrm{~mL}$ of $150-3000 \mu \mathrm{g} / \mathrm{L}$ $\mathrm{Cd}\left(\mathrm{NO}_{3}\right)_{2}$ or $\mathrm{Cu}\left(\mathrm{NO}_{3}\right)_{2}$. The solution was then shaken at 25 ${ }^{\circ} \mathrm{C}$ for $20-24 \mathrm{~h}$ and filtered using a $0.45 \mu \mathrm{m}$ membrane filter (ADVANTEC). The copper or cadmium concentration in the filtrate was then measured using an inductively coupled plasma-atomic emission spectrometer (ICP-AES, ICP-7000, Shimadzu). The amounts adsorbed were calculated using Eq. (4), as follows:

$$
X=\left(C_{0}-\mathrm{C}\right) \times 50 / 1000 / W
$$

where $X$ is the amount adsorbed $(\mu \mathrm{g} / \mathrm{g}), C_{0}$ is the initial concentration $(\mu \mathrm{g} / \mathrm{L}), C$ is the equilibrium concentration $(\mu \mathrm{g} / \mathrm{L})$, and $W$ is the adsorbent weight $(\mathrm{g})$.

The $\mathrm{pH}$ of the solution was measured using a $\mathrm{pH}$ meter (Mettler Toledo International Inc.).

\subsection{Effect of contact time on the adsorption of copper and cadmium}

The effect of contact time on the adsorption of copper or cadmium onto biomass was measured as follows: $0.05 \mathrm{~g}$ of biomass was added to $50 \mathrm{~mL}$ of $3000 \mu \mathrm{g} / \mathrm{L} \mathrm{Cd}\left(\mathrm{NO}_{3}\right)_{2}$ or $\mathrm{Cu}$ $\left(\mathrm{NO}_{3}\right)_{2}$. The solution was shaken at $25^{\circ} \mathrm{C}$ for $1,3,6,12,16$, 20 , and $24 \mathrm{~h}$. The copper and cadmium contents of the filtered solutions were measured by ICP-AES. The amount adsorbed with time was calculated, as above, using Eq. (4).

\subsection{Desorption of copper and cadmium using $\mathrm{HNO}_{3}$}

The desorption of copper or cadmium by $\mathrm{HNO}_{3}$, which was obtained from Wako Pure Chemical Industries Co. Ltd., was investigated as follows: $0.5 \mathrm{~g}$ of biomass was added to $200 \mathrm{~mL}$ of $3000 \mu \mathrm{g} / \mathrm{L} \mathrm{Cd}\left(\mathrm{NO}_{3}\right)_{2}$ or $\mathrm{Cu}\left(\mathrm{NO}_{3}\right)_{2}$. The adsorption experiment was conducted as above. The desorption experiment employed the biomass that had absorbed either copper or cadmium and was left to dry in a desiccator. The post-adsorption biomass was added to $20 \mathrm{~mL}$ of either a 0.01 or $1.00 \mathrm{~mol} / \mathrm{L} \mathrm{HNO}_{3}$ solution and shaken at $25^{\circ} \mathrm{C}$ for $24 \mathrm{~h}$. The copper and cadmium contents of the filtered solutions were measured using ICP-AES. The amount desorbed was calculated using Eq. (5), as follows: 


$$
D=C \times 20 / 1000 / W
$$

where $D$ is the amount desorbed $(\mu \mathrm{g} / \mathrm{g}), C$ is the equilibrium concentration $(\mu \mathrm{g} / \mathrm{L})$, and $W$ is the adsorbent weight (g).

\section{RESULTS AND DISCUSSION}

\subsection{Characteristics of $C G$ and $R B$}

Table 1 shows the characteristics of CG and RB. The CG and $\mathrm{RB}$ lipid contents were 7.8 and $16.1 \%$, respectively. The amount of crude protein in defatted biomass was greater than that in untreated biomass due to the relative increase in the amount of nitrogen in defatted biomass. The iodine adsorption ability indicates the specific surface area of the materials; the iodine adsorption ability was greater for CG than D-CG, whereas the iodine adsorption abilities of RB and D-RB were similar. Acid or base consumption indicates all of the acidic or basic functional groups on the surface materials. The acid and base consumption of D-CG was increased and decreased, respectively, compared with that of $\mathrm{CG}$, whereas the reverse

$\mathrm{Cu}$

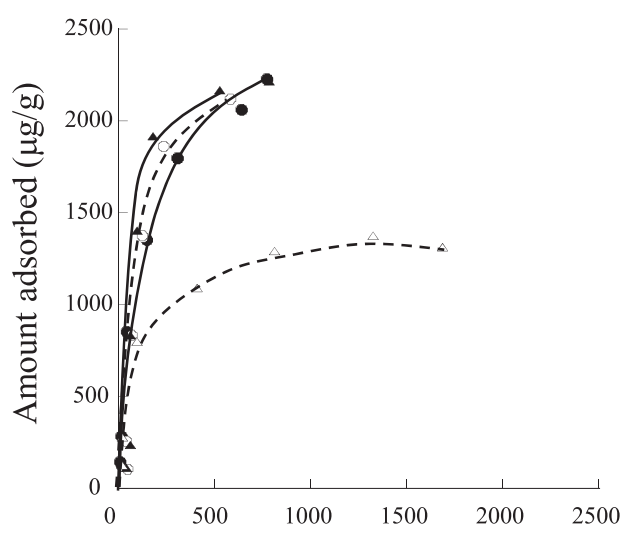

trend was seen with D-RB. Moreover, CG acid consumption was not detected.

\subsection{Adsorption isotherms of copper and cadmium onto biomass}

The amount of copper and cadmium adsorbed by CG and $\mathrm{RB}$ is shown in Fig. 1. The amount of copper adsorbed onto CG was similar to that onto D-CG: the adsorption of copper onto CG was not dependent on the presence of fat. In contrast, the amount of copper adsorbed onto D-RB was less than that onto $\mathrm{RB}$, indicating that $\mathrm{RB}$ copper adsorption was affected by the amount of fat or basic functional groups (Table 1 indicates that the number of basic functional groups on the RG surface decreased in defatted biomass). The amount of cadmium adsorbed onto CG was similar to that onto D-CG; therefore, as in CG copper adsorption, CG cadmium adsorption was not affected by the presence of fat. These results indicate that the amount of copper or cadmium adsorbed onto CG was not dependent on the amount of fat. However, the amount of cadmium adsorbed onto D-RB was less than that onto RB, indicating that $\mathrm{RB}$ cadmium adsorption was affected by the presence

$\mathrm{Cd}$

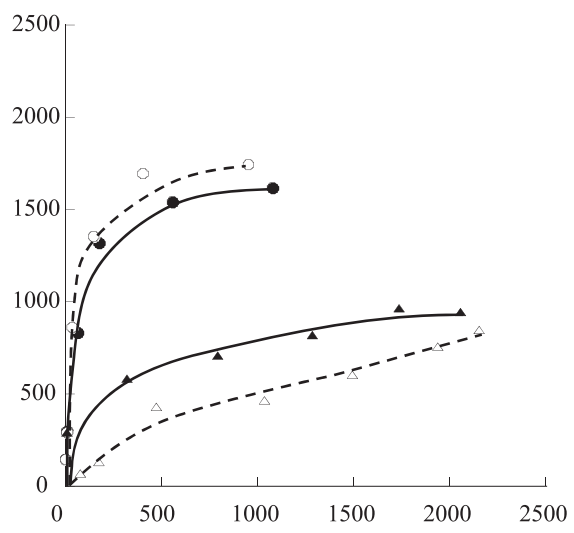

Equilibrium concentration $(\mu \mathrm{g} / \mathrm{L})$

Fig. 1 Amount of copper and cadmium adsorbed by $\mathrm{CG}$ and $\mathrm{RB}$

: $\mathrm{CG}, \bigcirc$ : D-CG, $\triangle$ : RB, $\triangle$ : D-RB

Table 1 Characteristics of CG and RB

\begin{tabular}{|c|c|c|c|c|c|c|}
\hline Sample & $\begin{array}{l}\text { Lipid } \\
(\%)\end{array}$ & $\begin{array}{c}\text { Total nitrogen } \\
(\%)\end{array}$ & $\begin{array}{l}\text { Protein } \\
(\%)\end{array}$ & $\begin{array}{l}\text { Ability of iodin } \\
\text { adsorption } \\
(\mathrm{mg} / \mathrm{g})\end{array}$ & $\begin{array}{c}\text { Acid } \\
\text { consumption } \\
(\mathrm{mmol} / \mathrm{g})\end{array}$ & $\begin{array}{c}\text { Base } \\
\text { consumption } \\
(\mathrm{mmol} / \mathrm{g})\end{array}$ \\
\hline CG & 7.8 & 1.82 & 11.4 & 228 & N.D.* & 0.92 \\
\hline D-CG & - & 2.10 & 13.1 & 188 & 0.07 & 0.89 \\
\hline $\mathrm{RB}$ & 16.1 & 2.23 & 14.0 & 243 & 0.18 & 0.63 \\
\hline D-RB & - & 2.89 & 18.1 & 239 & 0.03 & 0.87 \\
\hline
\end{tabular}

*: Non Detected 
Table 2 Freundlich constants of copper and cadmium adsorption onto $\mathrm{CG}$ and $\mathrm{RB}$ in a single solution system

\begin{tabular}{|c|c|c|c|c|}
\hline \multirow{2}{*}{\multicolumn{2}{|c|}{ Sample }} & \multicolumn{3}{|c|}{ Freundlich model } \\
\hline & & $1 / n$ & $\log K$ & $r$ \\
\hline \multirow{4}{*}{$\mathrm{Cu}$} & CG & 0.55 & 1.86 & 0.973 \\
\hline & D-CG & 0.73 & 1.29 & 0.794 \\
\hline & $\mathrm{RB}$ & 0.85 & 1.08 & 0.800 \\
\hline & D-RB & 0.61 & 1.45 & 0.881 \\
\hline \multirow{4}{*}{$\mathrm{Cd}$} & CG & 0.27 & 2.28 & 0.931 \\
\hline & D-CG & 0.28 & 2.41 & 0.910 \\
\hline & $\mathrm{RB}$ & 0.21 & 2.28 & 0.991 \\
\hline & D-RB & 0.72 & 0.55 & 0.982 \\
\hline
\end{tabular}

of fat or basic functional groups. It is possible that a proportion of the copper or cadmium adsorbed onto RB was dependent on fat or basic functional groups. Moreover, CG were more suitable for copper or cadmium adsorption than $\mathrm{RB}$. The $\mathrm{pH}$ of the post-adsorption solution increased to the alkaline region.

The data for the adsorption of copper or cadmium onto biomass were fitted to the Freundlich equation (6). Therefore, the adsorption ability is evaluated by its constants, $K$ and $1 / n$, as per

$$
\log V=1 / n \log C+\log K
$$

where $V$ is the amount adsorbed $(\mu \mathrm{g} / \mathrm{g}), C$ is the equilibrium concentration $(\mu \mathrm{g} / \mathrm{L})$, and $n$ and $K$ are adsorption constants. Constant $1 / n$, which is the slope of the Freundlich linear equation, numerically represents the affinity of the adsorbent for the adsorbate; constant $K$, an ordinate intercept, numerically represents the relationship of the adsorbent-adsorbate affinity to which the volume of adsorbate is added $^{28)}$. When $1 / n$ is in the range of $0.1-0.5$, the adsorbate is considered to be easily adsorbed. On the other hand, if $1 / n>2$, adsorption is considered to be difficult ${ }^{29)}$. The data shown in Fig. 1 were applied to the Freundlich equation and $\log K$ and $1 / n$ were calculated (Table 2 ). For the adsorption of copper and cadmium, the $1 / n$ value was in the range of $0.21-0.85$, which is less than 2 . These results indicate that adsorption is not difficult. The Freundlich plot shows a linear line with correlation coefficients of 0.794 0.991, suggesting accordance with the Freundlich equation. Since the Freundlich equation is based on the monolayer adsorption theory, the adsorption behavior of copper or cadmium onto $\mathrm{CG}$ or RB might be monolayer.

\subsection{Effect of contact time on the adsorption of copper and cadmium}

Contact time is one of the important parameters for the successful practical usage of adsorbents. The effect of contact time on the adsorption of copper and cadmium was investigated. As shown in Fig. 2, the equilibrium adsorption

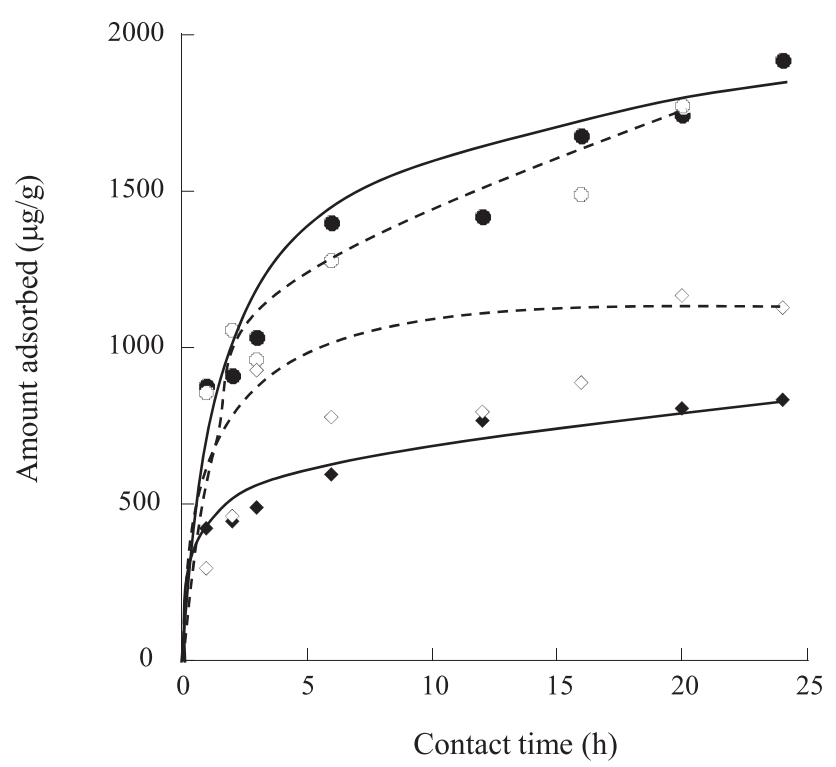

Fig. 2 Effect of contact time on the adsorption of copper and cadmium by $\mathrm{CG}$ and $\mathrm{RB}$

: $\mathrm{RB}-\mathrm{Cu}, \bigcirc: \mathrm{CG}-\mathrm{Cu}, \diamond: \mathrm{RB}-\mathrm{Cd}, \diamond: \mathrm{CG}-\mathrm{Cd}$

Table 3 Kinetic parameters for copper and cadmium adsorption onto $\mathrm{CG}$ and $\mathrm{RB}$

\begin{tabular}{ccccc}
\hline \multirow{2}{*}{ Sample } & \multicolumn{3}{c}{ Pseudo-second-order kinetic model } \\
\cline { 3 - 5 } & & $Q_{e}(\mu \mathrm{g} / \mathrm{g})$ & $k$ & $r$ \\
\hline \multirow{2}{*}{$\mathrm{Cu}$} & $\mathrm{CG}$ & 1784.1 & $2.7 \times 10^{-4}$ & 0.891 \\
& $\mathrm{RB}$ & 1926.4 & $2.4 \times 10^{-4}$ & 0.923 \\
& $\mathrm{CG}$ & 1164.9 & $2.2 \times 10^{-4}$ & 0.892 \\
$\mathrm{C}$ Cd & $\mathrm{CG}$ & 833.7 & $6.1 \times 10^{-4}$ & 0.945 \\
\hline
\end{tabular}

of copper or cadmium was established within $15-25 \mathrm{~h}$. The amount of copper adsorbed onto CG and RB was $1784 \mu \mathrm{g} / \mathrm{g}$ and $1926 \mu \mathrm{g} / \mathrm{g}$, respectively, while the amount of cadmium adsorbed onto CG and RB was $1165 \mu \mathrm{g} / \mathrm{g}$ and $834 \mu \mathrm{g} / \mathrm{g}$, respectively. In this study, $3 \mathrm{~h}$ after the start of adsorption, the amount of copper adsorbed onto CG and RB was 959 $\mu \mathrm{g} / \mathrm{g}$ and $1032 \mu \mathrm{g} / \mathrm{g}$, respectively, while the amount of cadmium adsorbed onto CG and RB was $929 \mu \mathrm{g} / \mathrm{g}$ and $489 \mu \mathrm{g} / \mathrm{g}$, respectively. When the concentration of copper or cadmium in aqueous environments is taken into consideration, a $3 \mathrm{~h}$ contact time is sufficient for using adsorbents for water purification.

In this study, the adsorption data were analyzed using the pseudo-second-order model. Experimental data were also fitted to the pseudo-second-order model ${ }^{30)}$, which is given as Eq. (7), as follows:

$$
t / Q_{t}=1 / k Q_{e}^{2}+\left(1 / Q_{e}\right) t
$$

where $k$ is the rate constant of the second-order equation $(\mathrm{g} / \mu \mathrm{g} \mathrm{h}), Q_{t}$ is adsorption time $t(\mathrm{~h})$ and $Q_{e}$ is the adsorption equilibrium $(\mu \mathrm{g} / \mathrm{g})$. 
This model is more likely to predict the kinetic behavior of adsorption with chemical sorption being the rate-controlling step ${ }^{31)}$. The rate constant $(k)$ and the $r$ and $Q_{e}$ values are given in Table 3. The pseudo-second-order model showed a correlation coefficient $(r)$ average of $0.891-$ 0.945 . These high $r$ values show that the adsorption of copper or cadmium onto CG or RB is well-matched to the pseudo-second-order kinetic model, which is based on the assumption that the rate-limiting step may be chemisorption.

\subsection{Desorption of copper and cadmium using $\mathrm{HNO}_{3}$}

Table 4 lists the percentages of copper and cadmium recovered by $\mathrm{HNO}_{3}$. The amount of copper and cadmium desorbed from CG using $0.01 \mathrm{~mol} / \mathrm{L} \mathrm{HNO}_{3}$ was $840.8 \mathrm{mg} / \mathrm{g}$ (desorption percentage: 89\%) and $758.2 \mathrm{mg} / \mathrm{g}$ (desorption percentage: $86 \%$ ), respectively. On the other hand, the amount of copper and cadmium desorbed from RB was $1082.4 \mathrm{mg} / \mathrm{g}$ (desorption percentage: $97 \%$ ) and $570.2 \mathrm{mg} / \mathrm{g}$ (desorption percentage: 90\%), respectively. These results show that $0.01 \mathrm{~mol} / \mathrm{L} \mathrm{HNO}_{3}$ is useful for the desorption of copper and cadmium from waste biomass. The percentages of copper or cadmium desorbed using $1.00 \mathrm{~mol} / \mathrm{L} \mathrm{HNO}_{3}$ were in the range of $82-113 \%$, thereby showing similar results to those using $0.01 \mathrm{~mol} / \mathrm{L} \mathrm{HNO}_{3}$. As mentioned above, the adsorbed copper or cadmium could be recovered using $\mathrm{HNO}_{3}$. These results indicate more efficient recovery than that reported by Sari and Tuzen ${ }^{32)}$. Interestingly, only a relatively low concentration of $\mathrm{HNO}_{3}$ was required for copper or cadmium desorption, with a concentration of $0.01 \mathrm{~mol} / \mathrm{L}$ being more suitable than $1.00 \mathrm{~mol} / \mathrm{L}$. We showed that the copper or cadmium adsorbed using waste biomass could be recovered.

\section{CONCLUSION}

The results show that the amount of copper or cadmium adsorbed using CG was larger than that using RB. The

Table 4 Amount of copper and cadmium desorbed using $\mathrm{HNO}_{3}$

\begin{tabular}{ccccc}
\hline & \multicolumn{2}{c}{$\mathrm{Cu}$} & \multicolumn{2}{c}{$\mathrm{Cd}$} \\
\cline { 2 - 5 } $\mathrm{HNO}_{3}$ & $\mathrm{CG}$ & $\mathrm{RB}$ & $\mathrm{CG}$ & $\mathrm{RB}$ \\
$(\mathrm{mol} / \mathrm{L})$ & \multicolumn{3}{c}{ Amount desorbed $(\mu \mathrm{g} / \mathrm{g})$} \\
\hline \multirow{4}{*}{0.01} & 840.8 & 1082.4 & 758.2 & 570.2 \\
& $(89)$ & $(97)$ & $(86)$ & $(90)$ \\
\multirow{2}{*}{1.00} & 993.0 & 1266.9 & 768.3 & 518.3 \\
& $(105)$ & $(113)$ & $(88)$ & $(82)$ \\
\hline
\end{tabular}

Amount adsorbed: $\mathrm{Cu}-\mathrm{CG}, \mathrm{Cu}-\mathrm{RB}, \mathrm{Cd}-\mathrm{CG}$ and $\mathrm{Cd}-\mathrm{RB}$ was $942 \mu \mathrm{g} / \mathrm{g}, 1121 \mu \mathrm{g} / \mathrm{g}, 878 \mu \mathrm{g} / \mathrm{g}$ and $635 \mu \mathrm{g} / \mathrm{g}$, respectively. amount of copper or cadmium adsorbed was not affected by the presence of fat in CG. On the other hand, the amount of adsorbed copper or cadmium using RB was affected by the presence of fat or basic functional group. The adsorption data were fitted to the Freundlich equation to generate correlation coefficients of 0.794-0.991. Moreover, the percentage of copper and cadmium desorbed using $0.01 \mathrm{~mol} / \mathrm{L} \mathrm{HNO}_{3}$ was in the range of $86-97 \%$, which indicates that the copper or cadmium adsorbed by waste biomass could be recovered.

\section{ACKNOWLEDGEMENTS}

This work was financially supported by "Antiaging Center Project" for Private Universities from the Ministry of Education, Culture, Sports, Science and Technology, 2008-2012.

\section{References}

1) Anwar, J.; Shafique, U.; Zaman, W.; Salman, M.; Dar, A.; Anwar, S. Removal of $\mathrm{Pb}$ (II) and Cd(II) from water by adsorption on peels of banana. Bioresour. Technol. 101 (6), 1752-1755 (2010).

2) Azouaou, N.; Sadaoui, Z.; Makaddem, H. Removal of cadmium from aqueous solution by adsorption on vegetable wastes. J. Applied Sci. 8(24), 4638-4643 (2008).

3) Doyurum, S.; Celik, A. Pb (II) and Cd(II) removal from aqueous solutions by olive cake. J. Hazard. Mater. B 138(1), 22-28 (2006)

4) Fiol, N.; Villaescusa, I.; Martinez ,M.; Miralles, N.; Poch, J.; Serarols, J. Sorption of $\mathrm{Pb}$ (II), $\mathrm{Ni}$ (II), $\mathrm{Cu}$ (II) and $\mathrm{Cd}$ (II) from aqueous solution by olive stone waste. Sep. Purif. Technol. 50(1), 132-140 (2006).

5) Horsfall, M. Jr.; Abia, A.A. Sorption of cadmium(II) and zinc(II) ions from aqueous solutions by cassava waste biomass (manihot sculenta Cranz). Water Res. 37 (20), 4913-4923 (2003).

6) Ibrahim, S.C.; Hanafiah, M.A.K.M.; Yahya, M.Z.A. Removal of cadmium from aqueous solution by adsorption on sugarcane bagasse. Am-Euras. J. Agr. Environ. Sci. 1 (3), 179-184 (2006).

7) Kumar, U.; Bandyopadhyay, M. Sorption of cadmium from aqueous solution using pretreated rice husk. Bioresour. Technol. 97, 104-109 (2006).

8) Leyva-Ramos, R.; Bernal-Jacome, L.A.; Acosta-Rodriguez, I. Adsorption of cadmium(II) from aqueous solution on natural and oxidized corncob. Sep. Purif. Technol. 45(1), 41-49 (2005).

9) Perez-Marin, A.B.; Zapata, V.M.; Ortuno, J.F.; Aguilar, M.; Saez, J.; Lorens, M. Removal of cadmium from 


\section{F. Ogata, H. Tominaga, H. Yabutani and N. Kawasaki}

aqueous solutions by adsorption onto orange waste. $J$. Hazard. Mater. B 139, 122-131 (2007).

10) Rocha, C.G.; Zaia, D.A.M.; Silva, R.V.; Alfaya, A.A.S. Use of rice straw as biosorbent for removal of $\mathrm{Cu}$ (II), $\mathrm{Zn}$ (II), Cd (II) and $\mathrm{Hg}$ (II) ions in industrial effluents. J. Hazard. Mater. 166 (1), 383-388 (2009).

11) Bhattacharyya, G.; Gupta, S.S. Kaolinite, montmorillonite, and their modified derivatives as adsorbents for removal of $\mathrm{Cu}$ (II) from aqueous solution. Sep. Purif. Technol. 50 (3), 388-397 (2006).

12) Jiang, M.Q.; Jin, X.Y.; Lu, X.Q.; Chen, Z.L. Adsorption of $\mathrm{Pb}$ (II), $\mathrm{Cd}$ (II), $\mathrm{Ni}$ (II) and $\mathrm{Cu}$ (II) onto natural kaolinite clay. Desalination 252, 33-39 (2010).

13) Al-Ghouti, M.A.; Li, J.; Salamh, Y.; Al-Laqth, N.; Walker, G.; Ahmad, M.N.M. Adsorption mechanism of removing heavy metals and dyes from aqueous solution using date pits solid adsorbent. J. Hazard. Mater. 176 (1-3), 510-520 (2010).

14) Buhani; Suharso; Sumadi Adsorption kinetics and isotherm of Cd(II) ion on Nannochloropsis sp biomass imprinted ionic polymer. Desalination (2010) in press.

15) Figuerie, M.M.; Volesky, B.; Mathieu, H.J. Instrumental analysis study of iron species biosorption by sargassum biomass. J. Mathieu, Environ. Sci. Technol. 33 (11), 1840-1846 (1999).

16) Krishnani, K.K.; Meng, X.; Christodoulatos, C.; Boddu, V.M. Biosorption mechanism of nine different heavy metals onto biomatrix from rice husk. J. Hazard. Mater. 153(3), 1222-1234 (2008).

17) Patel, R.; Suresh, S. Kinetic and equilibrium studies on the biosorption of reactive black 5 dye by Aspergillus foetidus. Bioresour. Technol. 99(1), 51-58 (2008).

18) Sari, A.; Tuzen, M. Biosorption of cadmium(II) from aqueous solution by red algae (Ceramium virgatum) : equilibrium, kinetic and thermodynamic studies. J. Hazard. Mater. 157 (2-3), 448-454 (2008).

19) Bun-Ei, R.; Kawasaki, N.; Ogata, F.; Nakamura, T.; Aochi, K.; Tanada, S. Removal of lead and iron by vegetable biomass in drinking water. J. Oleo Sci. 55(8), 423-427 (2006).

20) Kawasaki, N.; Bun-Ei, R.; Ogata, F.; Nakamura, T.; Tanei, S; Tanada, S. Water treatment technology using carbonaceous materials produced from vegetable biomass. J. Water Environ. Technol. 4(1), 73-82 (2008).

21) Kawasaki, N.; Tominaga, H.; Ogata, F.; Kakehi, K. Removal of cadmium and copper by vegetable biomass treated with hydrochloric acid. Chem. Eng. J. 157, 249-253 (2010)

22) Ogata, F.; Kawasaki, N.; Saeki, M.; Kakehi, K.; Tanada, S. Removal ability of copper and cadmium by biomass treated with enzymes. Yosui to haisui, 50 (5), 43-49 (2008).

23) Soxlhet, F. Die gewichtsanalytische bestimmung des milchfettes. Polytech. J. 232, 461 (1879).

24) Khaodfiar, S.; Azizian, M.F.; Osathaphan, K.; Nelson, P. Copper, chromium, and arsenic adsorption and equilibrium modeling in an iron-oxide-coated sand, background electrolyte system. Water Air Soil Pollut. 119 (1-4), 105-112 (2000).

25) Boehm, H.P. Chemical identification of surface groups. Advan. Catalysis. 16, 179-274 (1966).

26) Boehm, H.P.; Diehl, E.; Heck, W.; Sappok, R. Surface oxides of carbon. Angew. Chem. 76(17), 742-751 (1964).

27) Boehm, H.P. Some aspects of the surface chemistry of carbon blacks and other carbons. Carbon. 32 (5), 759-769 (1994).

28) Abe, I.; Ishikawa, T.; Kondoh ,S. Science of Adsorption. Maruzen Press. Tokyo. p.104 (1991).

29) Abe, I.; Hayashi, K.; Kitagawa, M. Studies on the adsorption of surfactants on activated carbon. J. Jpn. Oil Chem. Soc. 25(3), 145-150 (1976).

30) Ho, Y.S.; McKay, G. Pseudo-second order model for sorption processes. Process Biochem. 34 (5), 451-465 (1999).

31) Sölener, M.; Tunali, S.; Özcan, A.S.; Özcanc, A.; Gedikbey, T. Adsorption characteristics of lead(II) ions onto the from aqueous solutions. Desalination 223(1-3), 308-322 (2008).

32) Sari, A.; Tuzen, M. Kinetic and equilibrium studies of $\mathrm{Pb}$ (II) and Cd (II) removal from aqueous solution onto colemanite ore waste. Desalination 249(1), 260-266 (2009). 